\title{
BISHOP LIGHTFOOT'S LITERARY WORK AT DURHAM.
}

Not many generations have passed since a Bishopric was regarded as the natural goal of a scholar's life, in which, with much leisure and a few occasional routine duties, he might devote himself almost exclusively to his studies. But those days have happily passed away, and the present danger is rather that in the demand for practical men of business capacity the claims of scholarship to be duly represented in the highest posts of the Church should be passed over. The calls upon a Bishop's time and energies are simply endless: the enormous growth of population during the past twenty or thirty years in most of the English dioceses has by no means been met by a few tardy subdivisions; and the administrator of a large diocese has his hands so full, that it seems an impossibility for him to save any time for literary work. Every parish demands individual attention, and looks for at least occasional personal visits; Confirmations must be multiplied until they are held annually within reach of every parish ; there is not a Church Society but looks to the Bishop to champion its cause in various centres ; Conferences, Committees, Organizations, Gatherings of special bodies, etc. tend to increase on every side; while the daily post alone brings in enough work to employ the time of one man. In such a life as this, how is it possible for a Bishop, however gifted, to secure any leisure for literary work?

It was such considerations as these that aroused a serious anxiety in every quarter, when the announcement appeared in the newspapers on January 28, 1879 that Professor Lightfoot had accepted the see of Durham in succession to Dr. Baring. With regard to the episcopal appointment, as such, the news was greeted with universal sa.tisfaction; but it was felt that the price would be altogether too great to pay for a powerful administrator in the Church if Dr. Lightfoot's new responsibilities should prevent him from giving to the world any more of the eagerly expected results of his lifework on the writers of the New Testament and the Apostolic Fathers. A scholar of less note, it was urged, might well be found to organize and guide even such a great and difficult diocese as that of Durham; but no one could fill Dr. Lightfoot's place as a teacher and an expositor.

In the three months which intervened between his appointment and his consecration, while he was still at Cambridge, letters kept continually pouring in upon the Bishop-elect from all manner of correspondents, imploring him to find time in some way or another to continue his literary labours; and Dr. Westeott's sermon at the consecration of his friend in Westminster Abbey, in which he sketched the ideal of a Bishop's work, contained an earnest plea for patient thought and study and wise counsel on deeper subjects than mere diocesan detail or development. To one and all of these appeals the Bishop himself returned one steadfast answer; ' he had not accepted the oversight of the diocese to neglect its duties. Experience would show, but he would not venture to predict, whether any time would be left him to continue his lit:rary work.'

Accordingly from his first entering on his new sphere he devoted himself unflinchingly to the administration of his diocese; and frequently for weeks or even months at a time he found it impossible in the pressure of other work to secure any leisure for literary production. While however throughout his episcopate his diocese held the first and paramount position in Bishop Lightfoot's thought and energy, he consistently kept before him as only a secondary responsibility the urgent claim which rested upon him as a scholar and a theologian to strive earnestly to finish the work which he had undertaken before he became a Bishop. It was this constant sense of a great duty incumbent upon him that led him to devote every leisure hour that could be spared from diocesan work to the prosecution of his literary labours.

It is not an easy matter to point to any definite time or occasion which the Bishop was able regularly to secure for his books in the midst of his busy life at Auckland Castle. In the earlier years of his life there his habit was to rise very early in the . morning, and lighting his own fire (which had been laid ready for him over-night) to make sure of two or three hours' quiet work in his bedroom before breakfast. But after a few years when the terrible strain that pressed upon bim began to tell upon his health, he reluctantly abandoned this plan as anything like a general rule.

When his constant engagements took him from home, he would sacrifice any personal convenience to return before night, or at least very early the following morning, in 
order to save as much time as possible. But even so the days at Auckland were seriously broken into. After breakfast hewent through his letters with his chaplains, reserving a certain number to answer with his own hand, amongst which were the numerous communications he constantly received from scholars in all parts of Europe. The preparation of sermons, speeches, charges, etc., necessarily occupied a great deal of attention. And though the position of Bishop Auckland saved him from a large number of the inconsiderate callers who, had he lived at Durham, would have occupied his time about matters that could have been dealt with as well by post, still there were not a few to whom an interview was really important, and who accordingly found their way to Auckland Castle. But with all these interruptions the last hour or two of the morning not unfrequently found the Bishop engaged with his literary work, and he was often able to keep the greater part of the evening for it. Unfortunately too he would day after day restrict his exercise to a short stroll in his park, and then return to his work for the rest of the afternoon. For a man who had been used to a considerable amount of walking, this loss of fresh air and exercise was a serious strain upon his health.

The habit which the Bishop had formed of turning to his books at every available opportunity, however short, was exemplified even in the smallest details. Thus on his constant railway journeys, or in his long drives to the outlying villages of his diocese, he always had with him as his constant companion 'a bag (familiarly known as 'the Pandect'), in which were ready to his hand books, literary periodicals, proof-sheets, etc., for reference at any spare moment.

There was however one great opportunity for uninterrupted work open to the Bishop, which he was not slow to seize. When August came round, and he was able to get away for a summer holiday, he would carry off his books to some retired spot-generally in Scotland, and by preference to Braemar, where the bracing air and the quiet enabled him to work freely-and there he wonld abandon himself once more to a student's life. His diocesan correspondence followed him even there, but it did not reach him until wid-day, and the mornings and most of the evenings were kept sacred for literary work. It was during these holidays that a great part of his introduction to the Ignatian Epistles was written.
In the great bulk of his literary work Bishop Lightfoot depended entirely on his own labours. He never employed an amanuensis; he rarely allowed any one else even to verify his references. The only relief which he would accept was the almost mechanical correction of the proof-sheets of the new editions, as they were called for, of his 'Epistles of S. Paul.' But latterly he entrusted more and more of his editing work to his chaplain, the Rev. J. R. Harmer, who had prepared the indices for the edition of S. Ignatius. In passing the sheets of his books through the press the Bishop spared no pains to ensure completeness in every detail ; thus, for instance, one sheet of Ignatius was kept back for months to enable him to add if possible an English rendering which would preserve the play upon words in какобаi $\mu \omega \nu$ in the Antiochene Acts of Martyrdom of S. Ignatius (\$ II).

One great secret of the Bishop's being able to produce such a monument of learning and research as his Ignatius in the midst of an exceptionally active episcopate was the unique store of knowledge which he brought with him from Cambridge, and the remarkable accuracy of memory which enabled him to apply it readily. Page after page was written currente calamo with few or no books of reference at hand, and with only a 'ver.' here and there in the margin where future verification was required. He also had in a marked degree the power of again taking up the thread of his work after an interruption without a moment's hesitation. The thought of his complete and minute command of the whole range of the first three centuries excites a keen regret that the pressure of other business in the first instance, and afterwards the state of his health, should have prevented him from carrying out his original project, of writing a full historical introduction to his articles on 'Supernatural Religion' before re-issuing them in book form.

It would however be an inaccuracy to imply that all the Bishop's interest and researches were confined solely to the period of the Early Fathers. Apart from the various topics of general and current interest which engaged his attention, he was a thorough enthusiast and expert on the subject of English Church history and antiquities, especially with regard to the unique heritage of his own diocese. He was among the first to claim for the Northumbrian mission of the seventh century its true position in the evangelization of England; and he was 
familiar with every detail of the ecclesiastical antiquities of Durham and Northumberland.

Auckland Castle came into his hands with few or no relics of the see: he left it a monument of the history of all his great predecessors from the days of Aidan himself. Stained glass windows, shields, episcopal seals, portraits, books, personal relicssuch as the one faulty inscription of Butler, or the desk of Cosin-all tell the story of the past. In the summer of 1886 he began to prepare a monograph on the history of Auckland Castle, at. which he continued to work to the end as occasion offered. His sermons on the north country saints, preached at various churches dedicated in their names, will form a series which in point of Early English Church history will carry far more than a merely temporary or local interest. The Bishop himself intended to publish these in a collected form when he had completed the whole cycle, according to the plan he had laid down for himself.

When Dr. Lightfoot was appointed to Durham in 1879 there was some hope that he might be able to continue at intervals to give at the northern University some of the lectures on the Greek Testament which had made him so famous as a teacher at Cambridge. His official position as Visitor of the University and Patron of the Canonries, with which two of its Professorships are endowed, seemed to give a certain ground for asking this of him. On more than one occasion during the first two years of his residence in the north he was urged to undertake such a course of lectures. But nothing would induce him to accede to this request. He felt that his hands were more than full of work in other directions, while the teaching staff of the University was amply sufficient for its needs. His interest however in the University never flagged, and it found a practical expression in the foundation by him in 1882 of the De Bury Scholarship for students who intend to take Holy Orders in the diocese of Durham.

In his own home at Auckland Castle he gathered round him a band of graduates of the older Universities, who were reading with a view to taking Holy Orders in his diocese. The teaching of these students was entrusted chiefly to the resident chaplains, of whom there were always two on account of this special work. The Bishop himself occasionally gave them a course of Greek Testament lectures, and the general direction of their studies rested with him: but more than this he was unable to do. Altogether, in the ten years eighty of these students have been trained at Auckland.

The one impression left upon the minds of all who knew Bishop Lightfoot, on a review of his ten years' episcopate, must always be that of a Father of the Church, who set himself to rule over his diocese with conspicuous devotion, judgment, and ability; whose power of work seemed to be without limit, whose liberality was without stint; the motto of whose life was to spend and be spent for those to whom, as he himself expressed it on the day of his enthronement at Durham, he had given /himself wholly for better or worse. And when to all his other labours was added the strain of the Lambeth Conference of 1888, in which he bore no small part, it was the last burden which hopelessly broke down his already overtaxed strength. In the midst of a life of such ceaseless and varied activity, it was only by the steru exercise of his inflexible will, and a steadfast and self-denying earnestness of purpose, that he was able in any degree to continue his literary labours.

\section{H. E. Savage.}

' He was strong by that sobriety of judgment which commands the old, and that fire of enthusiasm which wins the young. His interest centred in the fulness of human life. Speculation had comparatively little attraction for him. Even this limitation of his intellectual character increased his influence and effectiveness in dealing with concrete facts. He shrank from indistinctness and indecision. Nothing visionary, nothing that men call mystical, marred the effect of his masculine reasoning . . . In argument and in exposition he preserved a true sense of proportion. His learning was always an instrument and not an end. No investigation of detail ever diverted his attention from the main issue. He mastered two outlying languages, Armenian and Coptic, in order to deal more surely with the secondary materials of the Ignatian controversy, but no ordinary reader would know the fact. For him the interpretation of ancient texts was a study in life. He held books to be a witness of something far greater, through which alone they could be understood. A Greek play or a fragmentary inscription, or a letter of Basil or a homily of Chrysostom, was to him a revelation of men stirred by like passions with ourselves, intelligible only 
through a vital apprehension of the circumstances under which they were written. $\mathrm{He}$ was a born historian. "How I long," he said to me more than once, " to write a history of the fourth century." If he has not written it, he has shown how it must be written.'

[Sermon preached at Westminster Abbey by Canon Westcott on the Sunday following the Bishop's death.]

- The interesting words just quoted will only deepen the feeling of regret with which, if we are not mistaken, scholars in general regarded the self-sacrificing obedience of Prof. Lightfoot to the call which removed him from a centre of thought and learning to the distractions of a busy and populous diocese. Granted that his influence as Bishop was of the highest value to the Church at large and to his own diocese in particu- lar, we have to set against this the heavy loss to Cambridge, which under the fostering care of himself and his brother professors had become perhaps the most important seed-plot of the Church in England; and, besides this, there is the thought of the added years of fruitful literary work which might have been hoped for if he had continued to reside in his University. Was it really necessary that our Beda should be forced to take up the work of a Ceadda as well ? However the past cannot be undone. It is some consolation that, as we are told, there is a prospect of a rich aftermath, including a much-enlarged edition of Clement, several volumes of sermons and addresses, an unfinished volume on the Northumbrian Saints, notes on the remaining Epistles of St. Paul, and possibly some notes on Aeschylus.-ED.

\section{ARCHAEOLOGY.}

\section{ROMAN INSCRIPTIONS FROM SARDINIA.-II.}

Signor Tamponi, the energetic Sardinian archaeologist who recently communicated to the Classical Review (iii. 228-233) an important find of milestones, has conferred a fresh favour by sending the inscriptions printed below, all of which, as I understand, are unpublished. At the editor's request I have added, as before, a few notes.

\section{F. Haverfield.}

\section{III.-Milestones.}

The following belong to the same series as those published in the Notizie (1888 p. 535) and in this Review (p. 228), being found near Olbia (Terranova), nos. 1-4 at Sbrangatu, no. 5 at Telti, on the Roman road to Carales (Cagliari). All are fragmentary, and are interesting mainly as being unpublished. The supplements in italics are inserted (conjecturally) for the reader's convenience only. The details given in italics are quoted from Sig. Tamponi.
5 10

The emperor's name, if the text be right, must be Septimius (Severus or Geta). The procurator's name cannot be restored : no known governor's name begins $M$. $P i$. ., nor, indeed, are nomina beginning in $P i$ at all common.

8 in.

2. Height 37 in., width 15 in., thickness

1. Height 32 in., circumference 42 in.

$$
\begin{gathered}
\text { M P CLX. . II } \\
\text { PIVS - FELIX Aug } \\
\text { PON'T MAXIMIS }
\end{gathered}
$$

Obviously one of the Constantines.

3. Height 52 in., width 16 in., thickness $12 \mathrm{in.}$

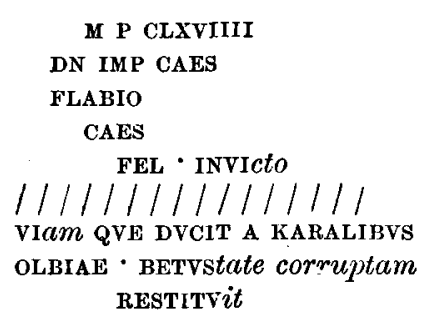

No. $\mathrm{XxX}$. VOL. IV. 